\title{
TIME MANAGEMENT AMONG MANAGERS IN THE POLLOG REGION
}

\section{Izet Zeqiri, Brikend Aziri, Jeton Mazllami}

(1) South East European University, Macedonia,

(2) University of Tetovo, Macedonia,

(3) South East European University, Macedonia

Brikend Aziri

University of Tetovo,

Tetovo, Macedonia

brikend.aziri@unite.edu.mk

Article info

Paper category: Preliminary paper

Received: 21.2.2017.

Accepted: 20.9.2017.

JEL classification: D23, J22, $\mathrm{P}_{25}$ 


\begin{abstract}
Time, the only non-replaceable resource is quite difficult to manage, although as it has been studied over and over again time management can be of crucial importance for a contemporary business organization. Individuals and managers in particular, must learn how to make the best out of their time and use time management as a tool in gaining and maintaining a competitive advantage. Although, researchers from throughout the world have managed to identify and develop hundreds if not even thousands of different time management approaches and techniques, it can be easily argued that such techniques are unknown when it comes to business in the Republic of Macedonia in general and the Pollog region in particular. But, the lack of a scientific approach does not necessarily mean a lack of dedication to a better usage of time by employees and managers alike. The paper strives to present the results of a rather extensive field research on time management implemented by the authors in over fifty business entities in the region.
\end{abstract}

\title{
Keywords:
}

Time; Time management techniques; Pollog region 


\section{INTRODUCTION}

Nowadays, in a period of intensified technological development, for people around the world, it has become more than obvious that perhaps the most valuable resource they have is time. In fact time might be perceived by some to be the only resource that provides sense to human life, a key resource in framing the existence of men as socially aware beans. But, the complexity in analyzing time and time management becomes even greater having in mind that time is not purely and simply a resource, but rather an element framing and interconnecting mankind past, present and future.

Time is a unique resource. It cannot be bought, nor borrowed, nor rented, stolen nor can it be replaced or substituted by anything else. Aside from this, time is the only resource equally distributed to everyone and everywhere. We all have the same 168 hours a week at our disposal. The way how we use these hours makes the difference between success and failure in business and even life in general.

Different fields provide various explanations of the concept of time, but they are debatable and skeptical. Much time work has been done in philosophy, classical and modern physics, biological sciences, and some in anthropology and sociology disciplines. Mathematics and classical physical science think that time has an abstract dimension. A Newtonian assumes that time is absolute, true, and mathematical, flows uniformly, and is abstract and external to events. However, Einstein's famous relativity theory describes that a slowing of time for clocks with a constant velocity is related to a referent observer (Wu, 2010).

But we do know what time is. We experience it. We measure it. As it is invisible and indefinable we use metaphors to grasp some of its aspects. Time is money - yes, it is a limited and valuable resource, but it is actually more precious and cannot be stored in the bank. Time is our lives as measured out in years, months, days, hours, minutes and seconds. What could be more important to you than using this free gift of time effectively, generously and wisely (Adair\&Allen, 2003)?

Time management refers to using techniques that enable you to get more done in less time and with better results, be more relaxed, and have more time to enjoy your work and your life. New managers in particular often struggle with the increased workload, the endless paperwork, the incessant meetings, and the constant interruptions that come with a management job. Learning to manage their time effectively is one of the greatest challenges that new managers face (Daft, 2016).

Time management is about making best use of time. You can't expand the number of hours available; you can simply use them more effectively. Inevitably there comes a point when even the best time manager can't get through what has to be done. Think of it as 'saturation point'. The problem is that you can feel as if you've reached saturation point' when in fact what's needed is better time management. It's very easy to miss underlying causes and habits which make you feel stressed and run out of time (Leech, 2007). 
Time management is not optional. It is something that everyone who wants to work effectively must consider, whether formally or informally. In fact, virtually everyone practices time management to some degree; the only question is how well they do it and how it affects what they do. Yet, time management is not easy - as you may have noticed! Nor, even for those who work at it, is it something that anyone gets 100 per cent right (Forsyth, 2007).

Managers who have mastered time management stand out a mile for being able to achieve more in every day than most other managers achieve in a week. And the most effective also get to spend their evenings and weekends with their family and friends, rather than being stuck in the office trying to clear the backlog of work (Jay, 2002).

Schermerhorn (2013) provides several personal time management tips:

- Do say "No" to requests that divert you from what you really should be doing.

- Don't get bogged down in details that you can address later

- or leave for others.

- Do have a system for screening telephone calls, e-mails, and requests for meetings.

- Don't let drop-in visitors or instant messages use too much of your time.

- Do prioritize what you will work on in terms of importance and urgency.

- Don't become calendar-bound by letting others control your schedule.

- Do follow priorities and work on the most important and urgent tasks first.

Time management is absolutely critical. Plan ahead using goal setting and todo lists. Control-or even better, eliminate-interruptions and distractions. When you have work appointments (online, phone, Skype, etc.), keep them; and make sure you're prepared by having the materials you will need for the conversation. Respect the schedules and time requirements of your colleagues. Finally, build in the kind of accountability you'd have in a traditional work arrangement. Recruit your manager or a colleague to be your accountability partner. Let them know what you intend to accomplish that day (or week) and check in daily (or weekly) to discuss what you've accomplished (Robbins\&Coulter, 2016).

Effective managers usually have good time management skills. Time management skills refer to the manager's ability to prioritize work, to work efficiently, and to delegate work appropriately (Griffin, 2016).

\section{DESCRIPTION OF SAMPLE}

The template sample includes 52 managers controlling 320 employees from the very same 52 companies from the Pollog region. The following table includes basic data regarding the companies that were part of the survey. 
Table 1.: Companies included in the survey

\begin{tabular}{|c|c|c|}
\hline Description & $\mathbf{n}$ & $\%$ \\
\hline \multicolumn{3}{|c|}{ Type of business activity } \\
\hline Trade & 36 & 69.2 \\
\hline Production & 7 & 13.5 \\
\hline Services & 4 & $7 \cdot 7$ \\
\hline Agriculture & 1 & 1.9 \\
\hline Construction & 4 & $7 \cdot 7$ \\
\hline \multicolumn{3}{|c|}{ Type of ownership } \\
\hline Sole ownership & 42 & 80.8 \\
\hline Partnership & 4 & $7 \cdot 7$ \\
\hline Limited liability company & 6 & 11.5 \\
\hline
\end{tabular}

Source: Authors'

As can be notices, the vast majority of companies that were a part of the survey are sole ownership business that deals with trade. Such composition of the sample is in accordance with the general structure of business in this region.

The following table contains data regarding the demographic structure of responding managers.

Table 2.: Demographic structure of managers

\begin{tabular}{|c|c|c|}
\hline Description & $\mathbf{n}$ & $\%$ \\
\hline \multicolumn{3}{|c|}{ Sex } \\
\hline Male & 42 & 80.7 \\
\hline Female & 10 & 19.3 \\
\hline \multicolumn{3}{|c|}{ Age } \\
\hline $18-25$ & 14 & 26.9 \\
\hline $26-35$ & 13 & 25 \\
\hline $36-45$ & 14 & 26.9 \\
\hline $46-65$ & 11 & 21.2 \\
\hline \multicolumn{3}{|c|}{ Education } \\
\hline Only primary school & 2 & 3.84 \\
\hline Only secondary education & 23 & 44.23 \\
\hline Higher education & 20 & 38.46 \\
\hline Bachelors degree & 5 & 9.61 \\
\hline Master's degree & 2 & 3.84 \\
\hline \multicolumn{3}{|c|}{ Work experience } \\
\hline Less than a year & 3 & $5 \cdot 7^{6}$ \\
\hline $1-2$ years & 7 & 13.46 \\
\hline $2-4$ years & 7 & 13.46 \\
\hline $4-10$ years & 16 & $3 \circ .76$ \\
\hline $10-20$ years & 10 & 19.23 \\
\hline
\end{tabular}




\begin{tabular}{|c|c|c|}
\hline Description & $\mathbf{n}$ & $\%$ \\
\hline Over 20 years & 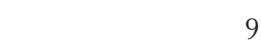 & 17.3 \\
\hline \multicolumn{3}{|c|}{ Job position } \\
\hline CEO & 28 & $5^{3.84}$ \\
\hline Middle level manager & 13 & 23.1 \\
\hline Low level manager & 11 & 21.1 \\
\hline
\end{tabular}

Source: Authors'

As can be noted from the data presented in the table above, over $3 / 4$ of respondents are men, almost half of the managers have never gotten a degree over high school, but the fact that $1 / 3$ of them have accumulated over a en year experience being a manager is prove enough that they are doing something well when it comes to managing their daily operations. It should also be pointed out that over half of respondents are CEO's of their respective businesses.

\section{DATA ANALYSIS}

The data analysis shows that companies in the Pollog region are aware of the importance of time management in determining the chances for their market success but some of them are more successful in the implementation of time management techniques.

Table 3.: Time management activities in the Pollog region

\begin{tabular}{|l|r|r|r|}
\hline & Always & \multicolumn{1}{|c|}{ Sometimes } & Never \\
\hline I prepare a daily to do list & 24 & 21 & 7 \\
I plan the day ahead & 39 & 9 & 4 \\
I have a schedule of to do activities & 36 & 13 & 3 \\
I have a daily list of personal objectives & 13 & 21 & 18 \\
I spend time planning daily & 12 & 24 & 16 \\
I have clear goals for the upcoming week & 34 & 16 & 2 \\
I set priorities and oblige to them & 46 & 5 & 1 \\
I do thing because I can't refuse people & 22 & 25 & 5 \\
I spend more time on preparation than & 30 & 17 & 5 \\
on doing & & & 5 \\
I believe my time management skills can & 32 & 15 & 1 \\
be improved & 34 & 17 & 5 \\
I use my time constructively & 25 & 22 & 2 \\
I am engaged in not for profit activities & 45 & 5 & 4 \\
I usually keep a clean desk & 42 & 6 & 13 \\
I set objectives for a three month period & 28 & 11 & 0 \\
I work night as well & 37 & 15 & \\
I am aware of time management & & & 5 \\
techniques & & & 5 \\
\hline
\end{tabular}

Source: Authors' 
The following can be noted from the above mentioned data:

- A vast majority of managers prepare a daily to do list. In fact only $13.46 \%$ of respondents never prepare a daily to do list of activities.

- Around $3 / 4$ of respondents have declared that they always plan the day ahead and only $7.69 \%$ of respondents never plan the day ahead.

- Only $5 \%$ of respondents do not have a schedule of to do activities.

- Only a quarter of responding managers permanently prepare a daily list of personal objectives and around 4,0\% sometimes prepare a daily list of personal objectives

- Only $23 \%$ of respondents permanently spend time planning daily while $46.15 \%$ sometimes allocate time for daily planning.

- Over $65 \%$ of respondents have clear goals for the upcoming week and only $3 \%$ of respondents do not have clear goals for the upcoming week.

- Over $88 \%$ of responding managers have declared that they permanently set priorities and oblige to them while only $2 \%$ of responding managers have declared that they never set priorities in their job.

- $42 \%$ of responding managers have declared that they permanently find themselves doing things simply because they cannot say no to people while an additional 4,8\% have declared that they sometimes find themselves doing things simply because they cannot say no to people.

- Only 10\% of responding managers have declared that they spend more time on preparation than on doing.

- Only 10\% of responding managers have declared that there is not additional space for improving their time management.

- Only $1.92 \%$ of responding managers have declared that they donot use their time constructively.

- Only 3.84\% of respondents have declared that they do not keep a clean desk.

- Over $4 / 5$ of responding managers have declared that they have clear quarterly plans.

\section{CONCLUSIONS}

The study shows that managers in the Pollog region emphasize the importance of time management and in most cases they have established functional approaches to utilizing their time in accordance with the general business climate in the mentioned region. The establishment of daily, weekly and monthly goals appears to be one of the strong sides of these managers in terms of their time management skills, but their over confidence that they use their time in an effective way might prove to be one of the greatest obstacles in further developing their time management skills. Aside from this, the vety collectivist nature of the local culture is one of the main time stealers that these managers are being faced with. 


\section{REFERENCES}

Adair, John Eric, and Melani Allen. Time management \& personal development, Thorogood publishing, 2003.

Daft R. L. 2016. Management, Twelfth Edition. Cengage learning

Forsyth Patrick. 2007. Successful time management, Elsevier

Griffin R.W. 2016. Fundamentals of Management, Cengage Learning

Jay R. 2002. Time Management, Oxford

Leech C. 2007. Managing time: Learning made simple, Elsevier

Robbins, Stephen P., and Mary K. Coulter. Management 13E.Pearson 2016.

Schermerhorn. J.R. 2013. Management. Essex.

Wu D. 2010. Temporal Structures in Individual Time Management: Practices to Enhance Calendar Tool Design, 